\title{
THE EFFECT OF PRISCOL ON THE PERIPHERAL VENOUS PRESSURE
}

\author{
BY \\ K. BRAUN and C. H. FRYD \\ From the Rothschild-Hadassah University Hospital, Jerusalem
}

Received June 13, 1950

It seems established that the increase of venous pressure in congestive heart failure cannot be explained on a purely mechanical basis. Neither the back pressure theory which explains the rise of venous pressure as being due to damming of blood behind the failing heart, nor the hypothesis that the rise in venous pressure is caused by an increase of blood volume due to retention of salt and water has proved entirely satisfactory. Other regulating mechanisms have, therefore, recently come into the foreground.

McMichael (1949), in an elucidating review of cardiac venous congestion, emphasizes the role of venomotor regulations in congestive heart failure for maintaining and raising the venous pressure. Two pathways have been shown to be active: (i) the autonomic nervous system and (ii) changes in the composition of blood gases. Lewis and Landis (1930) observed dilatation of the veins of the arm and hand following sympathectomy, and this relaxation was shown to be independent of local temperature. Papper and Imler (1944) observed dilatation of the leg veins after sympathectomy and thought that diminution of the venous tone was the cause of this change. Gollwitzer-Meier and Bohn (1930) have shown that increase in the carbon dioxide content of the blood brought about contraction of veins through the medium of the venomotor nerves, which are included in the sympathetic fibres; they believe that this venoconstriction is caused by changes in the acidity of the blood flowing through the vasomotor centres. Starr (1943) reported that in asphyxia there is an increase in the arterial and venous pressure which is apparently caused by anoxia. Little (1949) recently suggested, from an analysis of existing published data, that a decrease in mixed venous $\mathrm{CO}_{2}$ is the common factor in heart failure that stimulates increased cardiac output and, through venoconstriction, decreased venous capacity. From these observations it is apparent that the tone of the muscular wall of the veins is influenced by venomotor regulation (Henderson, 1943).

The introduction of sympathicolytic drugs makes it possible to study in a more detailed manner the possible role of the autonomic nervous sytem in the production of an increased venomotor tone in heart failure. Relman and Epstein (1948) observed the effect of tetraethylammonium chloride (TEAC) on venous and arterial pressures in congestive heart failure of varying ætiology. This drug blocks transiently the synapses between the preganglionic and postganglionic fibres of the sympathetic nervous system. They found that TEAC caused a significant fall in venous pressure and some decrease in arterial pressure. After administration of digitalis two cases of heart failure lost their initial responsiveness to TEAC. Hayward (1948) reported observations in six patients suffering from hypertensive heart failure. He found that administration of tetræthylammonium bromide led to a fall in the blood pressure and a decrease of the venous pressure. These patients also experienced a temporary relief of orthopnœa and dyspnœa.

Hereunder we are reporting the effect of another sympathicolytic drug on the peripheral venous pressure. Priscol (2-benzyl-imidazoline-hydrochloride) blocks the sympathetic motor pathways 
by action on the nerve terminals in smooth muscle (Nickerson and Goodman, 1946), but also counteracts the constrictive effects of epinephrine-like substances, which are formed at the vascular myoneural junction (Meyer, 1941). It is therefore considered to be an adrenolytic and sympathicolytic drug. Clinical observations have shown that it is a potent peripheral vasodilatator (Grimson et al., 1948).

\section{MATERIAL AND Methods}

Venous pressure was measured directly in an anticubital vein with a No. 18 or No. 19 gauge needle connected to an upright manometer and to a container holding saline solution. The measurements were taken after the patient had been resting in a recumbent position for half an hour. The zero point was placed at $4 \cdot 5-5 \mathrm{~cm}$. below the level of the sternocostal junction of the fourth rib. In instances where repeated measurements were taken the same vein was used. Arterial blood pressure was measured by sphygmomanometer and the heart rate was counted. After repeated estimation of venous pressure, pulse rate, and blood pressure had established a constant base line, $10 \mathrm{mg}$. priscol was injected intravenously through a fresh venipuncture on the opposite arm. All the measurements were repeated regularly during 30-40 minutes thereafter, the maximum effect of the drug appearing after 3-8 minutes; and after 20 minutes there was a return of the measurements to the values preceding injection. Twenty-two subjects were studied in this manner. Group I consisted of five control subjects with normal arterial and venous pressure. Group II contained four cases of essential hypertension without heart failure. Group III included three cases of hypertensive and arteriosclerotic heart disease with congestive heart failure. Group IV consisted of six cases of valvular heart disease with congestive heart failure. Group V contained four cases of chronic cor pulmonale with marked cyanosis and congestion. One patient of the fourth group and two of the fifth group were studied before and after full digitalization.

\section{RESULTS}

The results are summarized in Tables I, II, III, IV, and V which correspond to the numbers of the groups mentioned above. In the controls (Table I) the venous pressure rose in three patients

TABLE I

Controls Treated with Priscol

\begin{tabular}{|c|c|c|c|c|c|c|c|c|c|c|c|}
\hline \multirow[b]{2}{*}{ Diagnosis (Group I) } & & \multirow[b]{2}{*}{ Age } & \multirow[b]{2}{*}{ Sex } & \multicolumn{2}{|c|}{$\begin{array}{l}\text { Heart rate } \\
\text { per minute }\end{array}$} & \multicolumn{2}{|c|}{$\begin{array}{l}\text { Blood pressure } \\
\text { mm. Hg. }\end{array}$} & \multicolumn{2}{|c|}{$\begin{array}{l}\text { Mean arterial } \\
\text { pressure } \\
\text { mm./Hg. }\end{array}$} & \multicolumn{2}{|c|}{$\begin{array}{l}\text { Venous pressur } \\
\text { mm./norm. } \\
\text { saline }\end{array}$} \\
\hline & & & & $\begin{array}{l}\text { Before } \\
\text { priscol }\end{array}$ & $\begin{array}{c}\text { After } \\
\text { priscol } \\
\text { max. } \\
\text { change }\end{array}$ & $\begin{array}{l}\text { Before } \\
\text { priscol }\end{array}$ & \begin{tabular}{|} 
After \\
priscol \\
max. \\
change
\end{tabular} & $\begin{array}{l}\text { Before } \\
\text { priscol }\end{array}$ & $\begin{array}{l}\text { After } \\
\text { priscol } \\
\text { max. } \\
\text { change }\end{array}$ & $\begin{array}{l}\text { Before } \\
\text { priscol }\end{array}$ & $\begin{array}{c}\text { After } \\
\text { priscol } \\
\text { max. } \\
\text { change }\end{array}$ \\
\hline Jejunospasm (B.I.) & $\therefore$ & 55 & $\mathbf{M}$ & 72 & +4 & $\frac{120}{75}$ & $\frac{+15}{0}$ & 90 & +5 & 70 & +5 \\
\hline Diabetes mellitus (L.J.) & .. & 30 & $\mathbf{M}$ & 80 & -4 & $\frac{130}{90}$ & $\frac{+10}{0}$ & 103 & +4 & 97 & +28 \\
\hline Gastric ulcer (A.H.) & .. & 55 & $\mathbf{M}$ & 80 & +8 & $\frac{110}{80}$ & $\frac{+5}{0}$ & 90 & +2 & 30 & +30 \\
\hline Duodenal ulcer (M.A.) & . & 24 & $\mathbf{M}$ & 76 & +4 & $\frac{110}{80}$ & $\frac{0}{-10}$ & 90 & -7 & 70 & -10 \\
\hline Jejunal ulcer (Z.J.) & . & 48 & $\mathbf{M}$ & 64 & -4 & $\frac{115}{75}$ & $\frac{0}{0}$ & 88 & 0 & 45 & -5 \\
\hline
\end{tabular}


TABLE II

Effects of Priscol on Hypertension without Heart Failure

\begin{tabular}{|c|c|c|c|c|c|c|c|c|c|c|c|}
\hline \multirow[b]{2}{*}{$\begin{array}{l}\text { Diagnosis } \\
\text { (Group II) }\end{array}$} & \multirow[b]{2}{*}{ Age } & \multirow[b]{2}{*}{ Sex } & \multirow{2}{*}{$\begin{array}{c}\text { Circula- } \\
\text { tion } \\
\text { time } \\
\text { (secs.) }\end{array}$} & \multicolumn{2}{|c|}{$\begin{array}{l}\text { Heart rate } \\
\text { per minute }\end{array}$} & \multicolumn{2}{|c|}{$\begin{array}{c}\text { Blood pressure } \\
\mathrm{mm} . / \mathrm{Hg} .\end{array}$} & \multicolumn{2}{|c|}{$\begin{array}{c}\text { Mean arterial } \\
\text { pressure } \\
\mathrm{mm} . / \mathrm{Hg} .\end{array}$} & \multicolumn{2}{|c|}{$\begin{array}{c}\text { Venous pressure } \\
\text { mm./norm. } \\
\text { saline }\end{array}$} \\
\hline & & & & $\begin{array}{l}\text { Before } \\
\text { priscol }\end{array}$ & \begin{tabular}{|c|} 
After \\
priscol \\
max. \\
change
\end{tabular} & $\begin{array}{l}\text { Before } \\
\text { priscol }\end{array}$ & $\begin{array}{c}\text { After } \\
\text { priscol } \\
\text { max. } \\
\text { change }\end{array}$ & $\begin{array}{l}\text { Before } \\
\text { priscol }\end{array}$ & $\begin{array}{c}\text { After } \\
\text { priscol } \\
\text { max. } \\
\text { change }\end{array}$ & $\begin{array}{l}\text { Before } \\
\text { priscol }\end{array}$ & $\begin{array}{c}\text { After } \\
\text { priscol } \\
\text { max. } \\
\text { change }\end{array}$ \\
\hline $\begin{array}{l}\text { Essential hypertension } \\
\text { (K.J.) }\end{array}$ & 43 & $\mathbf{M}$ & 15 & 68 & +8 & $\frac{170}{115}$ & $\frac{+20}{+5}$ & 133 & +10 & 50 & +10 \\
\hline $\begin{array}{l}\text { Essential hypertension } \\
\text { (H.N.) }\end{array}$ & 65 & $\mathbf{M}$ & & 80 & +16 & $\frac{170}{110}$ & $\frac{-20}{-20}$ & 130 & -20 & 90 & -5 \\
\hline $\begin{array}{l}\text { Essential hypertension } \\
\text { (S.S.) }\end{array}$ & 59 & $\mathbf{F}$ & 11 & 86. & -8 & $\frac{140}{80}$ & $\frac{-20}{-10}$ & 100 & -13 & 85 & +15 \\
\hline $\begin{array}{l}\text { Essential hypertension } \\
\text { (R.Ch.) }\end{array}$ & 64 & $\mathbf{F}$ & 14 & 80 & +4 & $\frac{170}{95}$ & $\frac{-5}{0}$ & 120 & -2 & 65 & +15 \\
\hline
\end{tabular}

and in the other two there was a slight fall. The blood pressure increased somewhat in the three patients who showed a rise in the venous pressure, and in the other two it either decreased or did not change at all. In the patients with hypertension but without heart failure (Table II) there was an increase of the venous pressure in three and a slight drop in the fourth. The blood pressure increased in one of them and decreased in the remaining three. In Group III (hypertensive and arteriosclerotic heart disease with congestive heart failure) the venous pressure invariably dropped, the decrease ranging from 12 to $80 \mathrm{~mm}$. saline. The blood pressure increased slightly in one and decreased or did not change at all in the other two. Six patients with valvular heart disease and congestive heart failure (Table IV) showed a uniform response to the administration of priscol. The venous pressure dropped in all instances, the range being from 5 to $28 \mathrm{~mm}$. saline. The blood pressure, too, fell in every one of them (from 5 to $20 \mathrm{~mm}$. Hg.). Patients with chronic cor pulmonale and marked congestion (Table V) showed the most pronounced fall of the venous pressure; the drop ranged from 25 to $146 \mathrm{~mm}$. saline; the blood pressure fell in three of this group (5-15 mm. $\mathrm{Hg}$ ), while in the fourth there was no change.

TABLE III

Effects of Priscol in Hypertensive and Arteriosclerotic Heart Disease with Heart Failure

\begin{tabular}{|c|c|c|c|c|c|c|c|c|c|c|c|}
\hline \multirow{2}{*}{$\begin{array}{l}\text { Diagnosis } \\
\text { (Group III) }\end{array}$} & \multirow[b]{2}{*}{ Age } & \multirow[b]{2}{*}{ Sex } & \multirow{2}{*}{$\begin{array}{c}\text { Circula- } \\
\text { tion } \\
\text { time } \\
\text { (secs:) }\end{array}$} & \multicolumn{2}{|c|}{$\begin{array}{l}\text { Heart rate } \\
\text { per minute }\end{array}$} & \multicolumn{2}{|c|}{$\begin{array}{l}\text { Blood pressure } \\
\mathrm{mm} . / \mathbf{H g} .\end{array}$} & \multicolumn{2}{|c|}{$\begin{array}{c}\text { Mean arterial } \\
\text { pressure } \\
\text { mm./Hg. }\end{array}$} & \multicolumn{2}{|c|}{$\begin{array}{l}\text { Venous pressure } \\
\text { mm./norm. } \\
\text { saline }\end{array}$} \\
\hline & & & & $\begin{array}{l}\text { Before } \\
\text { priscol }\end{array}$ & $\begin{array}{c}\text { After } \\
\text { priscol } \\
\text { max. } \\
\text { change }\end{array}$ & $\begin{array}{l}\text { Before } \\
\text { priscol }\end{array}$ & $\begin{array}{c}\text { After } \\
\text { priscol } \\
\text { max. } \\
\text { change }\end{array}$ & $\begin{array}{l}\text { Before } \\
\text { priscol }\end{array}$ & $\begin{array}{c}\text { After } \\
\text { priscol } \\
\text { max. } \\
\text { change }\end{array}$ & $\begin{array}{l}\text { Before } \\
\text { priscol }\end{array}$ & $\begin{array}{c}\text { After } \\
\text { priscol } \\
\text { max. } \\
\text { change }\end{array}$ \\
\hline $\begin{array}{c}\text { Arteriosclerotic heart } \\
\text { disease (L.J.) }\end{array}$ & 66 & $\mathbf{M}$ & 28 & 88 & +12 & $\frac{130}{85}$ & $\frac{+10^{\prime}}{+5}$ & 100 & +7 & 180 & -80 \\
\hline $\begin{array}{l}\text { Hypertensive } \\
\text { disease (D.W.) }\end{array}$ & 51 & $\mathbf{F}$ & 25 & 68 & +4 & $\frac{220}{130}$ & $\frac{0}{0}$ & 160 & 0 & 132 & -12 \\
\hline $\begin{array}{l}\text { Hypertensive } \\
\text { disease (S.A.) }\end{array}$ & 55 & $\mathbf{F}$ & 15 & 76 & +4 & $\frac{170}{95}$ & $\frac{-5}{0}$ & 120 & -2 & 100 & -15 \\
\hline
\end{tabular}


TABLE IV

Effects of Priscol in Valuular Heart Disease with Heart failure

\begin{tabular}{|c|c|c|c|c|c|c|c|c|c|c|c|}
\hline \multirow{2}{*}{$\begin{array}{l}\text { Diagnosis } \\
\text { (Group IV) }\end{array}$} & \multirow{2}{*}{ Age } & \multirow[b]{2}{*}{ Sex } & \multirow{2}{*}{$\begin{array}{c}\text { Circula- } \\
\text { tion } \\
\text { time } \\
\text { (secs.) }\end{array}$} & \multicolumn{2}{|c|}{$\begin{array}{l}\text { Heart rate } \\
\text { per minute }\end{array}$} & \multicolumn{2}{|c|}{$\begin{array}{l}\text { Blood pressure } \\
\mathrm{mm} . / \mathrm{Hg} .\end{array}$} & \multicolumn{2}{|c|}{$\begin{array}{l}\text { Mean arterial } \\
\text { pressure } \\
\text { mm./Hg. }\end{array}$} & \multicolumn{2}{|c|}{$\begin{array}{l}\text { Venous pressure } \\
\text { mm./norm. } \\
\text { saline }\end{array}$} \\
\hline & & & & $\begin{array}{l}\text { Before } \\
\text { priscol }\end{array}$ & $\begin{array}{c}\text { After } \\
\text { priscol } \\
\text { max. } \\
\text { change }\end{array}$ & $\begin{array}{l}\text { Before } \\
\text { priscol }\end{array}$ & $\begin{array}{c}\text { After } \\
\text { priscol } \\
\text { max. } \\
\text { change }\end{array}$ & $\begin{array}{l}\text { Before } \\
\text { priscol }\end{array}$ & $\begin{array}{c}\text { After } \\
\text { priscol } \\
\text { max. } \\
\text { change }\end{array}$ & $\begin{array}{l}\text { Before } \\
\text { priscol }\end{array}$ & $\begin{array}{l}\text { After } \\
\text { priscol } \\
\text { max. } \\
\text { change }\end{array}$ \\
\hline Aortic Stenosis (A.E.) & 42 & $\mathbf{M}$ & $>50$ & 88 & +4 & $\frac{110}{90}$ & $\frac{-10}{0}$ & 97 & -4 & 190 & -18 \\
\hline $\begin{array}{l}\text { Mitral stenosis and in- } \\
\text { sufficiency (R.N.) }\end{array}$ & 31 & $\mathbf{M}$ & 44 & 82 & +2 & $\frac{140}{90}$ & $\frac{-15}{-5}$ & 107 & -9 & 260 & -28 \\
\hline $\begin{array}{l}\text { Mitral stenosis and in- } \\
\text { sufficiency (M.R.) }\end{array}$ & 42 & $F$ & & 100 & +20 & $\frac{110}{80}$ & $\frac{-20}{-20}$ & 90 & -20 & 190 & -25 \\
\hline Mitral stenosis (L.F.) & 44 & $\mathbf{M}$ & 18 & 80 & +4 & $\frac{120}{70}$ & $\frac{-15}{-5}$ & 87 & -9 & 100 & -5 \\
\hline $\begin{array}{l}\text { Mitral stenosis and in- } \\
\text { sufficiency + chronic } \\
\text { nephritis }\end{array}$ & 56 & $\mathbf{M}$ & 50 & 76 & +20 & $\frac{155}{100}$ & $\frac{-5}{-10}$ & 118 & -10 & 255 & -10 \\
\hline Mitral stenosis (K.Sh.) & 48 & $\mathbf{F}$ & 18 & 88 & +4 & $\frac{130}{80}$ & $\frac{-10}{-10}$ & 97 & -10 & 71 & -8 \\
\hline
\end{tabular}

It should be noted that in the first three patients of the last group there was also a decrease of the heart tate, while the fourth did not show any change. In all other cases of congestive heart failure there was an increase in the heart rate (ranging from 2 to 20 a minute), whereas the controls and the hypertensives without heart failure showed no uniform response (Tables I and II).

The effect of full digitalization $(1.5 \mathrm{mg}$. digitoxin) was studied in one case of Group IV and two cases of Group V. In the case of Group IV (A.E.) and one of Group V (P.Ch.), digitaiis caused a marked decrease of the venous pressure, while in the third case (Group V, A.J.) it had no

TABLE V

Effects of Priscol in Cor Pulmonale with Congestive Heart Failure

\begin{tabular}{|c|c|c|c|c|c|c|c|c|c|c|c|}
\hline \multirow{2}{*}{$\begin{array}{l}\text { Diagnosis } \\
\text { (Ǵroup V) }\end{array}$} & \multirow{2}{*}{ Age } & \multirow{2}{*}{ Sex } & \multirow{2}{*}{$\begin{array}{c}\text { Circula- } \\
\text { tion } \\
\text { time } \\
\text { (secs.) }\end{array}$} & \multicolumn{2}{|c|}{$\begin{array}{l}\text { Heart rate } \\
\text { per minute }\end{array}$} & \multicolumn{2}{|c|}{$\begin{array}{l}\text { Blood pressure } \\
\mathrm{mm} . / \mathrm{Hg} .\end{array}$} & \multicolumn{2}{|c|}{$\begin{array}{c}\text { Mean arterial } \\
\text { pressure } \\
\text { mm./Hg. }\end{array}$} & \multicolumn{2}{|c|}{$\begin{array}{l}\text { Venous pressure } \\
\text { mm./norm. } \\
\text { saline }\end{array}$} \\
\hline & & & & $\begin{array}{l}\text { Before } \\
\text { priscol }\end{array}$ & $\begin{array}{c}\text { After } \\
\text { priscol } \\
\text { max. } \\
\text { change }\end{array}$ & $\begin{array}{l}\text { Before } \\
\text { priscol }\end{array}$ & $\begin{array}{l}\text { After } \\
\text { priscol } \\
\text { max. } \\
\text { change }\end{array}$ & $\begin{array}{l}\text { Before } \\
\text { priscol }\end{array}$ & $\begin{array}{l}\text { After } \\
\text { priscol } \\
\text { max. } \\
\text { change }\end{array}$ & $\begin{array}{l}\text { Before } \\
\text { priscol }\end{array}$ & $\begin{array}{c}\text { After } \\
\text { priscol } \\
\text { max. } \\
\text { change }\end{array}$ \\
\hline Cor pulmonale (H.J.) & 65 & $\mathbf{M}$ & 16 & 96 & -4 & $\frac{145}{85}$ & $\frac{-15}{-15}$ & 105 & -15 & 150 & -68 \\
\hline $\begin{array}{l}\text { Cor pulmonale and } \\
\text { arteriosclerosis (P.Ch.) }\end{array}$ & 61 & $\mathbf{M}$ & 33 & 84 & -10 & $\frac{130}{80}$ & $\frac{-10}{-10}$ & 97 & -10 & 206 & $\rightarrow 146$ \\
\hline $\begin{array}{l}\text { Cor pulmonale and } \\
\text { arteriosclerosis (A.J.) }\end{array}$ & 55 & $\mathbf{M}$ & 23 & 96 & -12 & $\frac{110}{80}$ & $\frac{-5}{-5}$ & 90 & -5 & 230 & -30 \\
\hline Cor pulmonale (M.M.) & 48 &. $\mathrm{M}$ & 18 & 100 & 0 & $\frac{110}{80}$ & $\begin{array}{l}0 \\
\overline{0}\end{array}$ & 90 & 0 & 195 & -25 \\
\hline
\end{tabular}


effect upon it. The effect of priscol on the venous pressure changed after digitalization: in two cases the decrease was less than before digitalization, while in the third there was no decrease at all (Fig. 1) but rather a slight rise.

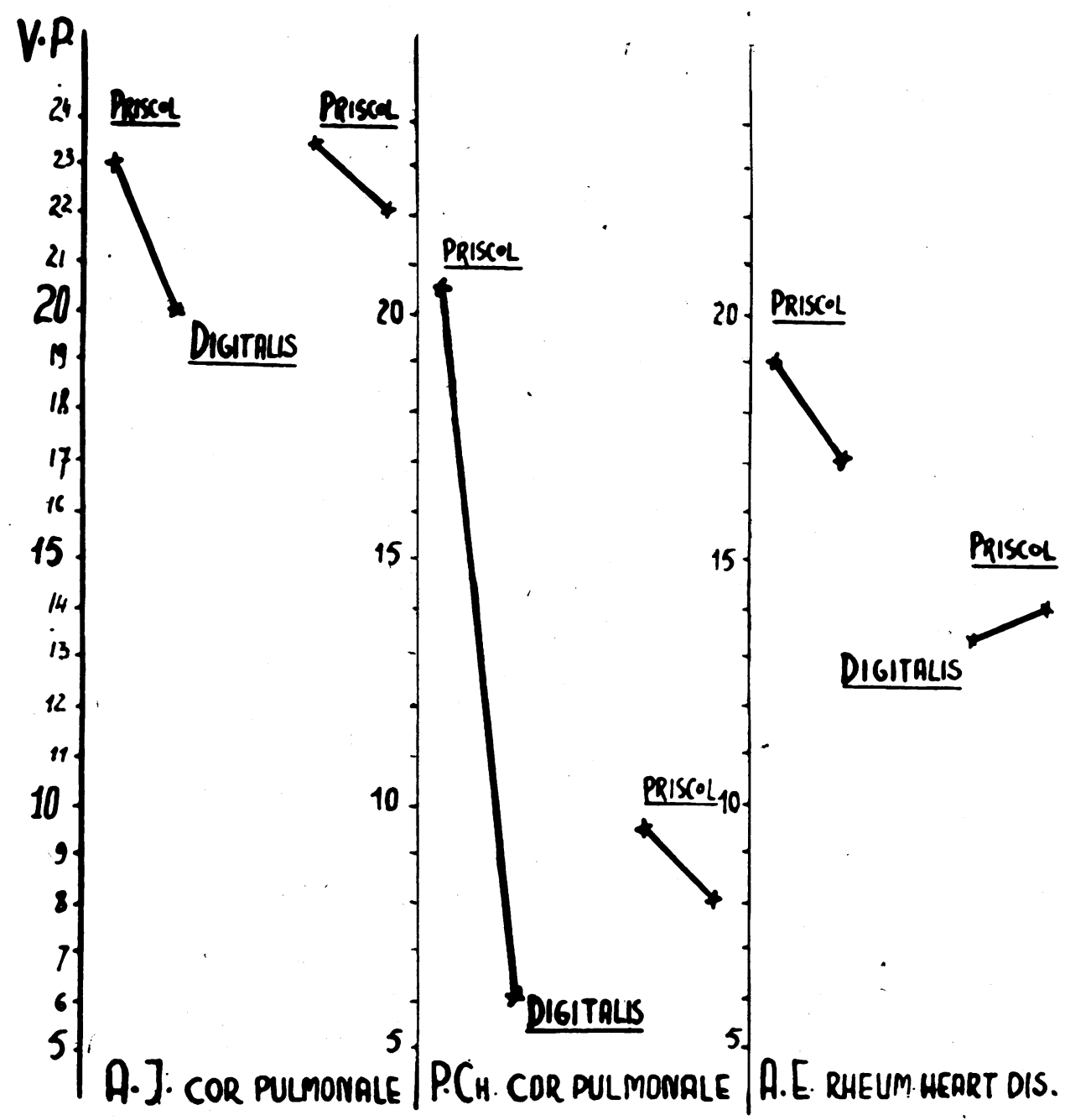

FIG. 1.-The effect of priscol on the venous pressure before and after digitalization. (For details, see text.)

\section{Discussion}

The observations of Grimson et al. (1948) and Wakim et al. (1950) have shown that priscol produces peripheral vasodilatation. This effect has been ascribed to its adrenolytic and sym-

pathicolytic properties. It has been shown that the vasodilating effect of the drug was greatest in the regions where venoconstriction was marked. Since the results of our investigation show a constant drop of the venous pressure in all cases of congestive heart failure, it has to be assumed that in all these cases a functional venoconstriction existed. This assumption is confirmed by the results in normal controls and, hypertensives without heart failure. The response of the venous pressure to priscol in these groups was different-the venous pressure rose somewhat in most instances or dropped insignificantly. This different response to the same sympathicolytic drug 
indicates a different state of the venous tone preceding injection. These observations suggest that in congestive heart failure an increased sympathetic activity causes venoconstriction, thus participating in the elevation of the venous pressure.

The most pronounced fall of the venous pressure was found in cases of cor pulmonale. This would indicate that venoconstriction in these cases is more pronounced. Since cor pulmonale is always accompanied by anoxia, the rise of venous pressure in this group may be partly related to the decreased oxygen tension of the venous blood and to the accumulation of metabolic products in anoxic tissues. These products may be of an adrenaline-like nature (Raab, 1941), and the marked effect of priscol in these cases could be explained by the counteracting effects of the drug on adrenaline-like substances. (Administration of 100 per cent oxygen in one case of cor pulmonale caused a marked drop of the venous pressure very similar to that observed after priscol.)

The fall in venous pressure after priscol could result from a primary myocardial action of the drug causing an increase of cardiac output and a better emptying of the decompensated heart. In fact a moderate increase of cardiac output has been reported by Siedek (1941). It seems to us, however, that in our cases the action of priscol was mainly peripheral, causing a release of the venoconstriction, since only in one patient with heart failure (Group III, Case LJ) was the drop in the venous pressure associated with a rise of the arterial pressure.

On the other hand the effect on the heart rate was not consistent: in Groups III and IV there was an increase, whilst the first three cases of Group $V$ showed a decrease and the fourth no change at all. Thus, the first three cases of Group $\mathrm{V}$ seem to prove most conclusively that the decrease in venous pressure was not mediated through an augmented cardiac output, but through the peripheral action of the drug, since in these cases there was a fall in the heart rate and a drop of the arterial pressure-findings that point clearly to a decrease of the cardiac output.

To study further the influence of the sympathetic nervous system on the venous pressure in congestive heart failure, a cold pressor test (Hines and Brown, 1932) was performed on four patients after the effect of priscol had disappeared, using the opposite arm to that in which the venous pressure was measured. - In all instances there was a marked rise of the venous pressure, the average being $25 \mathrm{~mm}$. These results show that sympathetic stimulation (cold pressor test) causes a rise or the venous pressure, probably through venoconstriction. The administration of digitalis in the three cases studied had a varying effect on the venous pressure, in two cases causing a decrease and in the third no change at all. Nevertheless, the response of the venous pressure to priscol after the digitalization was uniformly diminished, suggesting a change in the venomotor tone resulting from digitalis.

\section{SUMMARY}

The effects of priscol (a peripherally acting sympathicolytic drug) on the venous pressure were investigated in 22 cases. Five of them were controls without cardiovascular disease and four were cases of hypertension without heart failure; the remainder were patients with congestive heart failure of varying ætiology.

In the patients without congestive heart failure, administration of the drug caused either a small rise of the venous pressure or an insignificant drop. In patients with congestive heart failure there was a constant drop of the venous pressure; this was most pronounced in cases of cor pulmonale. The drop of the venous pressure was almost always accompanied by a fall in the arterial pressure.

It is conchuded that priscol lowers the venous pressure in congestive heart failure through its sympathicolytic action on the venous tone.

\section{REFERENCES}

Gollwitzer-Meier, K., and Bohn, H. (1930). Klin Wschr., 9, 872.

Grimson, K., Reardon, M. J., Marzoni, F. A., and Hendrix, J. P. (1948). Amer. J. Surg., $127,968$.

Hayward, G. W. (1948). Lancet, 1, 18.

Henderson, Y. (1943). Medicine, 22, 223. 
Hines, E. A., and Brown, G. E. (1932). Proc. Mayo Clin., 7, 332.

Lewis, T., and Landis, E. M. (1930). Heart, 15, 151.

Little, J. M. (1949). Amer. J. Med., 7, 207.

McMichael, J. (1949). Ibid., 6, 651.

Meyer, R. T. (1941). Helvet. med. Acta, 8, 18.

Nickerson, M., and Goodman, L. S. (1946). Fed. Proceed., 5, 161.

Papper, E. M., and Imler, A. E. (1944). Surgery, 16, 402.

Raab, W. (1941). Arch. interm. Med., 68, 713.

Relman, S. A., and Epstein, F. M. (1949). Proc. Soc. Exp. Biol., N.Y., Med., 70, 11.

Siedek, H. (1941). Z. klin. med., 139, 239, cited by Wakim.

Starr, I., Jeffers, W. A., and Meade, R. H., Jr. (1943). Amer. Heart J., 26, 291.

Wakim, K. G., Peters, G. A., and Horton, B. T. (1950). J. Lab. Clin. Med., 35, 50. 